University of South Carolina

Scholar Commons

7-1993

\title{
Omitted-Ability Bias and the Increase in the Return to Schooling
}

McKinley L. Blackburn

University of South Carolina - Columbia, BLACKBRN@MOORE.SC.EDU

David Neumark

University of Pennsylvania

Follow this and additional works at: https://scholarcommons.sc.edu/econ_facpub

Part of the Business Commons, and the Education Commons

\section{Publication Info}

Published in Journal of Labor Economics, Volume 11, Issue 3, 1993, pages 521-544.

http://www.jstor.org/action/showPublication?journalCode=jlaboreconomics

(C) 1993 by University of Chicago Press

This Article is brought to you by the Economics Department at Scholar Commons. It has been accepted for inclusion in Faculty Publications by an authorized administrator of Scholar Commons. For more information, please contact digres@mailbox.sc.edu. 


\title{
Omitted-Ability Bias and the Increase in the Return to Schooling
}

\author{
McKinley L. Blackburn, University of South Carolina
}

\author{
David Neumark, University of Pennsylvania and \\ National Bureau of Economic Research
}

Over the 1980s, there were sharp increases in the return to schooling estimated with conventional wage regressions. We explore whether the relationship between ability and schooling changed over this period in ways that would have increased the schooling coefficient in these regressions. Our empirical results reject the hypothesis that an increase in the bias of the schooling coefficient, due to a change in the relationship between ability and schooling, has contributed to observed increases in the return to schooling. We also find that the increase in the schooling return has occurred for workers with relatively high levels of academic ability.

\section{Introduction}

In the 1980s, the United States experienced considerable changes in the structure of wages paid to different demographic and educational groups. The most notable of these changes is a large increase in wage differences of white males at different educational levels, as the wages of more-educated workers increased relative to their less-educated counterparts. For instance, among white males between the ages of 25 and 34 in 1979, college graduates

We thank John B1shop, David Card, Bıll Carter, John Chilton, Elchanan Cohn, Andrew Foster, James Foster, Jacob Mincer, Paul Taubman, and semınar participants at the University of Pennsylvania, the University of Maryland, and Columbia University for helpful comments. Sadiq Currimbhoy provided excellent research assistance.

[Journal of Labor Economics, 1993, vol 11, no 3]

(C) 1993 by The University of Chicago All rights reserved

0734-306X/93/1103-0003\$01.50 
earned roughly $15 \%$ more than workers who had only completed high school; among 25-34-year-olds in 1987, college graduates earned 33\% more than high-school graduates. ${ }^{1}$ Blackburn, Bloom, and Freeman (1990/91) show that wage differences associated with education also increased for white females, while Katz and Revenga (1989) also point to increases in the 1980 s in wage differences associated with the level of labor market experience of white males.

Several studies have attempted to explain why education-related wage differentials increased in the 1980s. Perhaps the most commonly offered explanations have been associated with changes in the relative demand for workers at different educational levels. For example, it has been suggested that changes in international trade patterns have shifted relative labor demand curves in favor of the more educated. An associated explanation singles out shifts in the industrial structure of the economy toward serviceoriented production as the important factor. However, the available evidence suggests that these changes have at most played a minor role in the changes in earnings differentials. There is also evidence that changes in the supply of workers at different educational levels have contributed to the changes in earnings differentials, especially for younger white males, though the magnitude of this effect is sensitive to assumptions about the substitutability between more and less educated workers. An alternative explanation (discussed in Blackburn, Bloom, and Freeman [1990]) is that there are changes in the average level of productive ability of workers in different educational classes. ${ }^{2}$

There are several economic theories that suggest there might be a relationship between a worker's inherent ability (i.e., ability not affected by acquisition of schooling) and his level of schooling. In the following section, we discuss two such theories-a signaling model and a human-capital model. We also argue that it is possible that changes over time in the schooling-ability relationship have played a role in increasing the observed return to schooling. In particular, we suggest that an increase in the correlation between ability and schooling among cohorts entering the labor market could have caused an increase in the return to education without a corresponding increase in the "true" effect of schooling on wages. Alternatively, an increase in the price of ability could also lead to a spurious increase in the estimated return to schooling. Since most empirical studies of the increase in the return to schooling do not attempt to control for the

\footnotetext{
${ }^{1}$ These statistıcs are taken from table 1 of Blackburn, Bloom, and Freeman (1990). Similar findings are reported in, e.g., Katz and Revenga (1989).

${ }^{2}$ Kosters (1991, p. 16) suggests that "given the growing fraction of young people completing at least some college, those completing only high school might not be as able as earlier generations of students."
} 
effect of unobserved ability on wages, estimates of the increase in schooling returns could reflect a change in the schooling-ability relationship.

At the outset, we want to emphasize that changes in the relationship between ability and schooling can constitute only a partial explanation of recent changes in education-earnings differentials. This follows from the fact that these differentials have increased for older as well as younger workers, while changes in the ability-schooling relationship are most directly related to changes in the return to schooling for cohorts of workers entering the labor market. However, studies of recent changes in educationearnings differentials have generally found that increases in these differentials have been considerably larger among cohorts of workers just entering the labor market than among all prime-age workers. For example, Blackburn, Bloom, and Freeman (1990) report that the increase in the college/high-school differential from 1979 to 1987 for 25-34-year-olds was almost double the increase observed for the complete sample of 2564-year-olds. Katz and Murphy (1992) report a similar difference when comparing workers with 1-5 years of experience to workers at all experience levels. It is this additional increase in educational returns for the youngest workers (approximately half of the total increase) that we consider potentially explainable by changes in the schooling-ability relationship. ${ }^{3}$

But is it possible that the schooling-ability relationship could have changed sufficiently over an 8-year period so as to cause such a large increase in the observed return to education? This is in essence an empirical question, though there is some evidence suggesting that ability distributions (as reflected in test scores), as well as the ability-schooling relationship, should not be thought of as stable over time. For one, Bishop (1989) reports a large decline in the average score on basic-skills tests administered to students in Iowa (and similar tests in other states) that he argues is partially responsible for the fall in the rate of productivity growth. More important, Taubman and Wales (1972) present evidence from several studies that suggest that the difference in average test scores between students who contınue their education after completing high school and those who do not increased almost fivefold from 1925 to 1960 . While we are not aware of any evidence on changes in the relationship between test scores and schooling among cohorts entering the labor market in the 1980 s (prior to this study), past evidence suggests that the possibility of such changes deserves attention.

\footnotetext{
${ }^{3}$ Prior research has suggested that the larger increase in differentials for younger workers is due to the fact that supply changes have been more rapid for this group than for prime-age workers as a whole. However, estımates of the importance of this explanation depend on assumptions about the substitutability between college and high-school workers (see Katz and Murphy 1992) Research emphasizing this explanation has also generally tgnored substitution possibilittes between younger and older workers of the same education level.
} 
The empirical work in this article uses a sample of young white males from the National Longitudinal Survey (NLS) Youth Cohort. We use data on these individuals to estimate wage equations that attempt to control for (among other things) the effect of both schooling and "unobserved ability" on wages. The models we estimate take advantage of scores on several tests measuring academic (or cognitive) and technical ability that are avallable in the Youth Cohort data. These test scores are used as (potentially error-prone) measures of ability in wage equations. We also consider econometric problems that arise from the potential endogeneity of schooling choices with respect to wages for young workers.

Our empirical findings provide little or no support for the idea that changes in the relationship between ability and schooling in the 1980s are responsible for the increase in education-related earnings differentials. In fact, our results suggest that the correlation between ability and schooling fell over this period. However, we do find evidence that the increase in earnings differentials has occurred primarily for workers with higher academic ability.

\section{Theoretical Discussion of the Ability-Schooling Relationship}

In this section, we consider the effect that the relationship between omitted ability and schooling has on empirical estimates of the relationship between education and earnings and how changes in the ability-schooling relationship may change the estimated relationship between education and earnings. We assume a model for earnings that follows the form

$$
w=\beta_{1} S+\beta_{2} A+\varepsilon,
$$

where $w$ is the $\log$ of the wage, $S$ is an education variable, $A$ is an ability variable, and $\varepsilon$ is an error term distributed independently of $S$ and $A{ }^{4}$ Since $A$ is not observed in the data sets used in recent studies of changes in the return to schooling, these studies have used the simple-regression coefficient $b_{w s}$ as an estimate for $\beta_{1}$ (1.e., they estimate [1] omitting ability from the regression). This is a biased estimate, if $A$ and $S$ are correlated. In this section, we discuss two kinds of models that suggest a positive relationship between ability and schooling: the signaling model and a variant of the usual human capital model.

In simple signaling models, high-ability workers obtain more schooling than low-ability workers because schooling provides a signal to employers that they have high levels of ability (e.g., see Spence 1973). In a signaling

\footnotetext{
${ }^{4}$ The wage equation can be thought of as the partial relation of $w$ with $S$ and $A$, the correlation of other variables with $w, S$, and $A$ having been removed.
} 
model in which ability is a continuous variable, but the schooling signal is dichotomous (such as college versus no college), changes in the percentage of workers who obtain schooling should be associated with changes in the wage differential between educated and noneducated workers since the expected level of ability for educated and noneducated workers will be affected. ${ }^{5}$ In particular, an increase in the percentage of workers who obtain the schooling signal is likely to be associated with a decline in the wage differential (if educated workers remain a minority of workers after this increase).

Among 25-64-year-olds, the percentage of men who are college graduates increased from 1979 to 1987 , while the wage differential between college graduates and all other workers also increased. Since college graduates remained a minority of workers, an increase in this wage differential is the opposite of what the signaling model would predict. With more than two levels of schooling, however, simple predictions are not possible. In Blackburn and Neumark (1991), we performed simulations of the effects that observed changes in the percentages of workers in a four-way education classification would be expected to have on wage differentials. Though the percentage of workers who were college graduates did fall from 1979 to 1987 among 25-34-year-olds, these simulations suggested that a signaling model would imply associated changes in wage differentials that would be very small, and much smaller than the actual changes in observed wage differentials. Thus, it appears that a signaling model cannot explain the increased return to schooling in the 1980 s as a consequence of a change in the ability-schooling relationship.

A positive correlation between schooling and ability is also suggested by the human capital model of Becker (1975). In this model, ability increases the marginal benefit to an individual of acquiring schooling, while "opportunity" reflects individual differences that lower the marginal cost of schooling. Unless there is a sufficiently large negative correlation between ability and opportunity, the model predicts that those workers who choose more schooling will also tend to have higher levels of ability. Failure to control for ability in a wage regression should result in upward-biased estimates of the return to schooling. ${ }^{6}$

The Becker model can be used to consider the effect that changes in the distribution of ability and opportunity would have on the bias in the schooling coefficient estimates from wage regressions that omitted ability.

\footnotetext{
${ }^{5}$ The model assumes that the mean and variance of the ability distribution is stable over time. The model is presented in Blackburn and Neumark (1991)

${ }^{6}$ In this model, a worker's level of opportunity does affect their choice of schooling but does not otherwise affect the wage they expect to receive. Therefore, omission of measures of opportunity in the wage regression does not lead to additional bias in the schooling coefficient estimate.
} 
For instance, increases in the variance of ability, or in the size of the covariance between ability and opportunity, should increase this omittedability bias. Likewise, decreases in the variation in opportunity across individuals would also increase this bias. ${ }^{7}$ Since we know little about how ability/opportunity distributions have been changing in recent years, it is difficult to speculate on whether changes in this bias are likely. However, these results suggest that attempting to control for ability in wage regression estimates of the schooling-return increase is important. In the following section, we estimate wage models that use test scores as potential indicators of ability usually not captured in standard wage regressions. With these estimates, we can explore whether omission of ability has been important to the large increase in education-earnings differentials among young male workers.

\section{Empirical Analysis}

\section{A. Data}

The data we use come from the National Longitudinal Survey Youth (NLSY) Cohort. This cohort was first surveyed in 1979, when the respondents were between the ages of 14 and 22. They have been reinterviewed each year since 1979; we use data through the 1987 interview. The information extracted for each year includes wages on the current job, schooling status, labor market activity over the previous year, and industry, occupation, and union coverage on the current job. The 1979 interview also collected several variables associated with the family background of the respondent, which we use in our empirical analysis.

Most importantly, the data set includes scores of each respondent on the Armed Services Vocational Aptitude Battery (ASVAB) tests. Ten test scores are available, for a variety of cognitive and mechanical aptitudes. The test areas are general science, arithmetic reasoning, mathematics knowledge, word knowledge, paragraph comprehension, mechanical comprehension, numerical operations, electronic information, auto and shop information, and coding speed. The ASVAB tests were administered to all survey respondents between the 1979 and 1980 surveys, with a $94 \%$ completion rate. The availability of these test scores, along with the time period over which the data were collected, make the NLSY a useful data set for studying changes in education-related earnings differentials for young males in the early 1980 s and whether shifts in the ability-schooling relationship underlie these changes. ${ }^{8}$

7 These results are demonstrated in Blackburn and Neumark (1991)

${ }^{8}$ The NLSY has also not suffered from sample attrition to the same degree as earlier longitudinal labor-market surveys; by 1987, roughly $90 \%$ of the original cohort was still responding to interview requests. 
The NLSY data could be used in a variety of ways to measure earnings differentials for young workers. One possibility is to estimate wage equations for each year from 1979 to 1987 , using any respondent in the year who was working and was not in school. ${ }^{9}$ One problem with this type of analysis is that the sample in the later years will be increasingly made up of workers more established in their labor market positions; learning models suggest that schooling may become less important for wages, and ability more important, as workers accumulate experience, ${ }^{10}$ so that this analysis could confuse age (actually, experience) effects in the return to schooling with the desired period effects. To minimize this problem, we instead construct our sample so that we use only one wage for each respondent; the wage we choose is the first wage available after the respondent has completed his schooling (i.e., the respondent does not return to school by the 1987 wave of the survey). With this sample, we also capture workers for whom the increase in the return to schooling has been sharpest. The restriction to using only one wage per respondent makes it impractical to try to carry out an analysis of bias in schooling coefficients in regressions estimated separately for each year from 1979 to 1987 , so we allow our schooling coefficients to vary along a linear tıme trend over the 1979-87 period."

Sample means and standard deviations for many of the variables used in our wage-equation estimation are presented in the first column of table 1. The average age of our sample of workers on their first postschooling job is fairly young, though the amount of labor-market experience (i.e., hours worked in year-equivalent units) shows that on average our respondents had worked over 2 years before they enter the sample. (Much of this experience may have been obtaned in jobs held while in school.) The educational-attanment statıstics for our sample show slightly lower average education levels than other estimates for this cohort, probably because some of the eventually more-educated members of this cohort are still in school in 1987.

In column 2 of table 1, we report coefficient estimates from an individuallevel regression of some of the variables on a constant and a time trend. These estimates show how the composition of the sample changes as we

${ }^{9}$ Bishop (1991) uses a restricted version of this setup, in which coefficients in wage equations are allowed to vary along a linear trend over the sample period. Also, he does not restrict the sample to individuals who are out of school.

${ }^{10}$ See, e.g., Harris and Holmstrom (1982) and Farber and Gibbons (1990). Indeed, Farber and $\mathrm{G}_{1}$ bbons derive a further restriction that returns to ability will increase with experience, while returns to schooling will remain constant.

${ }^{11}$ We restrict the analysis to white males, for whom we have 2,451 observations. We exclude the self-employed, farm laborers, and respondents reporting a wage lower than one-half of the federal minimum wage prevallng in the year from which the observation is drawn. 
Table 1

Descriptive Statistics for First Postschooling

Labor Market Observation

\begin{tabular}{|c|c|c|}
\hline & Mean & Trend ${ }^{*}$ \\
\hline Log wage & $\begin{array}{l}1616 \\
(451)\end{array}$ & $\begin{array}{c}077 \\
(003)\end{array}$ \\
\hline Years of education & $\begin{array}{l}12729 \\
(2449)\end{array}$ & $\begin{array}{c}558 \\
(016)\end{array}$ \\
\hline $\begin{array}{l}\text { High school graduate ( } 12 \text { years) } \\
\text { College graduate ( } 16 \text { years) }\end{array}$ & $\begin{array}{l}423 \\
156\end{array}$ & . \\
\hline Experiencet & $\begin{array}{c}2180 \\
(1.754)\end{array}$ & $\begin{array}{c}395 \\
(012)\end{array}$ \\
\hline Age & $\begin{array}{l}20975 \\
(2740)\end{array}$ & $\begin{array}{c}685 \\
(017)\end{array}$ \\
\hline $\begin{array}{l}\text { Married, spouse present } \\
\text { Urban } \\
\text { Union }\end{array}$ & $\begin{array}{l}166 \\
710 \\
176\end{array}$ & 8 \\
\hline Number of observations & $2,451^{\circ}$ & \\
\hline 1979 & 463 & . \\
\hline 1980 & 315 & \\
\hline 1981 & 309 & \\
\hline 1982 & 341 & . . \\
\hline 1983 & 287 & \\
\hline 1984 & 228 & \\
\hline 1985 & 185 & \\
\hline 1986 & 168 & \\
\hline 1987 & 155 & \\
\hline \multicolumn{3}{|l|}{ Test scores (age-neutral) $\ddagger$} \\
\hline Academic test $\$$ & $\begin{array}{r}.012 \\
(.857) \\
{[-61, .69]}\end{array}$ & $\begin{array}{l}140 \\
(006)\end{array}$ \\
\hline Technical test $\|$ & $\begin{array}{r}-010 \\
(840) \\
{[-54,61]}\end{array}$ & $\begin{array}{c}065 \\
(007)\end{array}$ \\
\hline Computational test & $\begin{array}{r}010 \\
(976) \\
{[-.65,77]}\end{array}$ & $\begin{array}{c}119 \\
(008)\end{array}$ \\
\hline $\begin{array}{l}\text { Nonacademic test-technical } \\
+ \text { computational }\end{array}$ & $\begin{array}{r}000 \\
(1541) \\
{[-91,1.16]}\end{array}$ & $\begin{array}{c}184 \\
(012)\end{array}$ \\
\hline
\end{tabular}

NOTE - Standard deviations are reported in parentheses in col 1 Standard errors are reported in parentheses in col 2

* Coefficient from regression on intercept and time trend The time trend is defined as zero in 1979

+ Actual year equivalents of labor market expenence, constructed from weeks and hours worked in each year, and labor market history prior to the first survey in 1979

$\ddagger$ Residuals from regressions of normalized test scores on individual year age dummy variables Lower and upper quartiles are reported in square brackets

$\checkmark$ Average of residuals for tests of arithmetic, mathematics, word knowledge, paragraph comprehension, and general science

$\|$ Average of residuals for tests of auto and shop knowledge, electronics, and mechanical knowledge

move through the $1979-87$ period. The wage variable we use is a measure of hourly earnings (in current dollars) on the primary job held at the time of the interview; the trend coefficient shows that this wage has increased by almost $8 \%$ per year over the $1979-87$ period. While part of this increase 
is due to inflation, the increase also reflects the fact that individuals in the later years have a higher average level of education, have more experience at the time of the first postschooling job observation, and are older at the time of the first job. Wages in the later years may also be higher because returns to education (and experience) increased over the period.

Table 1 also reports sample statistics for averages of three subsets of the ASVAB test scores. Since the respondents were of different ages when the tests were administered, age effects were removed from the scores by regressing each of the individual (normalized) test scores on a set of individual-year age dummies (for all observations on white males for whom the test scores were available). The residuals from selected tests were then averaged to form the three composite test scores identified in table 1. Following Bishop (1991), we dropped the coding speed test and classified the remaining tests as either academic, technical, or computational; details of this classification are provided in the footnotes to the table. Because our wage-equation estimates suggest that the technical and computational composites have very similar effects on wages, we also present sample statistics for the sum of these two composites (the "nonacademic" test). The trend coefficients for the test scores show that all three composites tend to be higher for those individuals whose first jobs were in the later years, with the increase over time largest for the academic test and smallest for the technical test.

\section{B. Wage Equation Estımates}

Using our hourly wage variable, we initially estimate equations of the form

$$
w_{t}=\beta_{1} S_{\imath}+\beta_{2}\left(T, S_{t}\right)+\beta_{3} X_{\imath}+\beta_{4}\left(T_{t} X_{\imath}\right)+\beta_{5} Y_{2}+\varepsilon_{\imath},
$$

where $w$ is the log wage, $S$ is years of schooling, $T_{1}$ the value of the time trend for the year from which the observation is taken, $X$ is a vector of other factors that affect the wage, $Y$ is a set of year dummies, and $\varepsilon$ is an error term. The trend has a value of zero for the first year (1979) and increases by one for each subsequent year. Including year dummies effectively controls for variation in wages due to inflation, productivity growth, or other cyclical factors. The other variables included in $X$ are experience, age, a union membership dummy, a marriage dummy, and an urban dummy. ${ }^{12}$

\footnotetext{
${ }^{12}$ The ordinary least squares (OLS) estimates of trends in the coefficients of the marriage dummy and the urban dummy were near zero and statistically insignificant, so in our reported estimates we constrained these trends to be zero. In contrast, the estimated trends in the coefficients for age and union membership were statistically significant and negative, and the estimated trend in experience was positive and nearly statistically significant. Interactions of these variables with a time trend are included in all specifications.
} 
Ordinary least-squares estimates of $\beta_{1}$ and $\beta_{2}$ in equation (2) are reported in column 1 of table 2 . The results replicate the increased return to schooling in this period found in other data sets. ${ }^{13}$ The estimates suggest that the linear return to schooling was .032 in 1979 and that this coefficient has increased by .0034 in each following year; by 1987, the estimate for the return to schooling is .059 . This estimate for the increase in the return to schooling is somewhat larger than estimates suggested by previous studies, though other studies have used samples of workers who are older and more established than the workers in our sample.

To further explore the robustness of the increased return to schooling in the NLSY, in the remaining columns of table 2 we include other education-related variables as regressors to pick up nonlinear effects, while continuing to interact the years-of-education variable with a time trend. The linear specification could lead to incorrect inferences concerning the sign or magnitude of the increase in the return to schooling if the true relationship between schooling and log wages is nonlinear. This is potentially a serious problem in analyzing our sample since the individuals whose first jobs are from the earlier years tend to be less educated than the individuals from the later years. For example, if the return were higher for college than for high-school years of education, our finding that the return to schooling is higher in the later years studied could entirely be due to the fact that individuals from the later years have more years of college education.

In column 2 of table 2, we add years of college as an additional regressor; the estimates suggest the return to college years is higher than to precollege years, but including this variable only marginally reduces the education/ trend coefficient estimate. Including years of high school along with years of college (col. 3) reduces the education/trend coefficient estimate more and provides a statistically significant negative coefficient for high-school years, relative to pre-high school years of education. In column 4 we include a college graduate dummy, and in column 5 we include both a high-school graduate and a college graduate dummy; estimates of both specifications contınue to provide evidence of an increased return to schooling. In sum, nonlinear effects of schooling on log wages, combined with the nature of our sample, may explain some of the large increase in the return to schooling suggested in column 1, but even after controlling for these effects, we continue to see a reasonably large rise in the schooling coefficient.

${ }^{13}$ We also estımated separate wage equations for each year, using our sample of first labor-market observatıons. The schooling coefficient estımates are reported in App. table A1. These coefficients trend upward only approximately. However, we use the trend interaction to parameterize the model tightly, which is particularly important for the instrumental variable (IV) estimation that follows. Also, this parallels specifications in related research (Bishop 1991) 
Table 2

OLS Log Wage Equation Estimates

\begin{tabular}{|c|c|c|c|c|c|}
\hline & $(1)$ & (2) & (3) & (4) & (5) \\
\hline Years of education & $\begin{array}{c}.032 \\
(.007)\end{array}$ & $\begin{array}{l}.029 \\
.008)\end{array}$ & $\begin{array}{l}054 \\
(014)\end{array}$ & $\begin{array}{c}028 \\
.008)\end{array}$ & $\begin{array}{c}030 \\
(.008)\end{array}$ \\
\hline Years of education $\times$ trend & $\begin{array}{l}.0034 \\
(0017)\end{array}$ & $\begin{array}{r}0030 \\
(0017)\end{array}$ & $\begin{array}{c}.0018 \\
(0018)\end{array}$ & $\begin{array}{l}.0027 \\
(.0017)\end{array}$ & $\begin{array}{r}0023 \\
(0018)\end{array}$ \\
\hline Years of high school & & & $\begin{array}{l}-013 \\
(006)\end{array}$ & . & . \\
\hline Years of college & & $\begin{array}{c}002 \\
(.002)\end{array}$ & $\begin{array}{l}.001 \\
(002)\end{array}$ & & \\
\hline High school graduate & & $\ldots$ & & & $\begin{array}{l}-011 \\
(017)\end{array}$ \\
\hline College graduate & . & . & & $\begin{array}{l}080 \\
(024)\end{array}$ & $\begin{array}{l}.075 \\
(.025)\end{array}$ \\
\hline $\bar{R}^{2}$ & 393 & 393 & 394 & .396 & 396 \\
\hline
\end{tabular}

As discussed in Section II, all of the schooling coefficient estimates in table 2, and in particular the education/trend coefficient estimate, potentially suffer from biases resulting from the error term being partly composed of individual abilitıes not captured in $X$ and from changes in the correlations between these abilities and schooling. In table 3 , we attempt to provide some idea of the importance of omitted-ability bias by including our test score measures as proxies for this omitted ability. In column 1, we include the individual's academic, technical, and computational test scores as independent variables. As the coefficient estimates for the technical and computational tests are very close, and the coefficient estimate for the academic test is negatıve and statistically insignificant, we estimated a specification that excludes the academic test and includes the sum of the technical and computational tests; these results are in column 2. Both regressions provide highly significant coefficient estimates for the nonacademic test scores, and inclusion of the test scores reduces the estimates for the schooling coefficient at any point in time (e.g., in col. 1 the coefficient estimate for 1979 is .013 and for 1987 it is .051). However, the magnitude of the estimated increase in the schooling coefficient does not decline after including the test scores, but rather increases by nearly a third (.0048 in table 3, cols. 1 and 2 , vs. .0034 in table 2, col. 1$).^{14}$

${ }^{14}$ This result is due to the fact that, in our data set, the partial regression coefficient in the auxilıary regression of ability on schooling displays a statistically significant negative trend for the test scores that we use. Specifically, we regressed the test scores on all of the variables included in the wage equation, including the education / 
Table 3

OLS and IV Log Wage Equation Estimates, Including Test Scores with Constant Coefficients

\begin{tabular}{|c|c|c|c|c|c|c|c|c|}
\hline & \multicolumn{2}{|c|}{ OLS } & \multicolumn{2}{|c|}{ IV for Test Scores } & \multicolumn{2}{|c|}{$\begin{array}{l}\text { IV for Test Scores } \\
\text { and Schooling }\end{array}$} & \multicolumn{2}{|c|}{ IV for Schooling } \\
\hline & (1) & $(2)$ & (3) & (4) & (5) & (6) & (7) & $(8)$ \\
\hline Years of education & $\begin{array}{c}013 \\
(.008)\end{array}$ & $\begin{array}{c}012 \\
(008)\end{array}$ & $\begin{array}{l}-000 \\
(013)\end{array}$ & $\begin{array}{c}-001 \\
(013)\end{array}$ & $\begin{array}{c}029 \\
(045)\end{array}$ & $\begin{array}{c}022 \\
(.043)\end{array}$ & $\begin{array}{c}028 \\
(.021)\end{array}$ & $\begin{array}{c}024 \\
(018)\end{array}$ \\
\hline Years of education $\times$ trend & $\begin{array}{c}0048 \\
(.0017)\end{array}$ & $\begin{array}{c}0048 \\
(0017)\end{array}$ & $\begin{array}{c}0062 \\
(0023)\end{array}$ & $\begin{array}{c}0057 \\
(0018)\end{array}$ & $\begin{array}{c}0077 \\
(0047)\end{array}$ & $\begin{array}{c}0062 \\
(.0042)\end{array}$ & $\begin{array}{c}0084 \\
(.0029)\end{array}$ & $\begin{array}{l}0070 \\
(0030)\end{array}$ \\
\hline Academic test & $\begin{array}{c}-010 \\
(017)\end{array}$ & 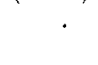 & $\begin{array}{l}-.057 \\
(152)\end{array}$ & $\ldots$ & $\begin{array}{l}-.110 \\
(155)\end{array}$ & . & $\begin{array}{c}-042 \\
(024)\end{array}$ & . \\
\hline Technical test & $\begin{array}{l}044 \\
(013)\end{array}$ & & & & . & & & \\
\hline Computational test & $\begin{array}{l}.041 \\
(010)\end{array}$ & $\cdots$ & $\cdot$ & $\cdots$ & $\cdots$ & $\cdots$ & & \\
\hline Nonacademic test & . & $\begin{array}{c}038 \\
(.006)\end{array}$ & $\begin{array}{c}094 \\
(081)\end{array}$ & $\begin{array}{c}064 \\
(020)\end{array}$ & $\begin{array}{l}083 \\
(081)\end{array}$ & $\begin{array}{c}035 \\
(044)\end{array}$ & $\begin{array}{c}042 \\
(008)\end{array}$ & $\begin{array}{l}028 \\
(009)\end{array}$ \\
\hline $\begin{array}{l}\vec{R}^{2} \\
\text { Measurement error/ } \\
\text { endogeneity tests. }\end{array}$ & 404 & 405 & & & & & . & \\
\hline$p$-value ${ }^{*}$ & & & 331 & 170 & 493 & 418 & 096 & 136 \\
\hline
\end{tabular}

NOTE - Specifications also include experience, age, and union status (each interacted with a time trend defined as zero in 1979), dummy variables for urban residence and marned, spouse present, and an intercept and single-vear dummy varıables Standard errors are reported in parentheses Instrumental variables are listed in App table A3 OLS

$=$ ordinary least squares, IV = instrumental variable estimation
$* p$-value from $F$-test of significance of coefficients of residuals from first-stage instrumental variables regressions, in log wage equation estimated with $O L S$ 
Simply including the test scores as regressors may not be the best way to use the information in these variables to control for "ability." It seems reasonable to expect that the productive ability that employers value is at least partly reflected in our test scores but that several other factors also affect the outcome of the tests (e.g., test-taking ability, sleep the previous night, etc.). We might write this process as

$$
\mathrm{TS}_{\imath}=\gamma A_{\imath}+\mathrm{v}_{\imath}
$$

where TS is the test score, $A$ is ability rewarded in the labor market, and $v$ is other factors that affect the test score. If we assume that $A$ and $v$ are uncorrelated, we have the classical errors-in-variables setup, suggesting that table 3's OLS estimates of the test score coefficients, and coefficients for variables correlated with the test scores, are inconsistent. As a remedy, we assume that ability is correlated with the family background of the individual through the equation

$$
A_{t}=\lambda F_{\imath}+\eta_{t}
$$

where $F$ is a vector of family-background variables. Instrumental variable estimation of the wage equation when the test score is included as a regressor, using $F$ as an instrument for TS, should eliminate the inconsistency in the wage-equation estimates resulting from measurement error in the test scores. ${ }^{15}$

Schooling and test-score coefficient estimates from estimations in which the test scores are treated as error-ridden are presented in columns 3 and 4 of table 3 . The family-background variables used as instruments are listed in the Appendix table A3, along with the coefficient estimates in the firststage regressions for the test scores. ${ }^{16}$ The wage-equation estımates show

trend variable For the academic test, the coefficient estımate (standard error) of this trend variable was $-.010(.003)$, while for the nonacademic test it was -.036 (.006). We also looked at changes in the ability-schooling relationship on a yearby-year basis, by regressing the test scores on education and the other variables included in the wage regression (omitting, in this case, the trend interactions); the schooling coefficient estimates from the regressions for academic and nonacademic test scores are reported in App. table A2.

${ }^{15}$ We assume that $F$ and $v$ are uncorrelated. Prior research suggests that it 15 reasonable to exclude family-background varıbles as regressors in a wage equation (see the discussion in Blackburn and Neumark [1992]). This method for controlling for unobserved ability was originally suggested by Griliches and Mason (1972); see also the surveys in Griliches (1977, 1979).

${ }^{16}$ For observations in which a family-background variable is missing, we set the variable to zero; we also include dummy variables for each family-background variable being missing. This is essentially a first-order regression method for handling missing regressors. This method is likely to provide inconsistent coefficient estimates (see Kmenta 1986), so the coefficient estimates we report in App. table A3 are likely biased estımates of $\lambda$. However, the inconsistency in these estimates should not affect the consistency of our estimates of the wage equation. 
the estimate of the "ability" effect to be larger than without instrumenting, as would usually be expected if the OLS coefficients suffered from measurement-error bias. The schooling coefficients also decline, for any given year, and appear to be essentially zero in the earliest years. But the increase in the return to schooling is slightly larger as a result of instrumenting for the test scores, again suggesting that omitted ability plays no role in explaining increases in the return to schooling. We also performed specification tests (suggested by Hausman [1978]) for the presence of measurement-error bias in the ability coefficient; the probability values for the null hypothesis of no measurement-error bias are also reported in table 3 . The specification tests do not provide strong evidence aganst the hypothesis that test scores are uncorrelated with the wage equation errors.

Our IV estimates may also be inconsistent if the level of schooling is not exogenous with respect to the postschooling wage. Models in which schooling decisions depend on the wage (e.g., human-capital models in which wages represent opportunity costs of schooling), or measurement error in the schooling variable (Griliches and Mason 1972), suggest that schooling may be correlated with the wage-equation error. Given the young age of the men in our sample, endogeneity is a potentially serious problem since the wages we observe are likely highly correlated with those relevant to their schooling decisions. To explore this possibility, we use our familybackground variables to instrument for both test scores and education; these results are reported in columns 5 and 6 of table $3 .{ }^{17}$ This technique does affect the point estimates for the schooling and ablity coefficients, but it also leads to a considerable increase in the standard errors associated with these coefficients. Most importantly, the increase in the return to schooling implied by the point estımates is even larger. Finally, if we instrument for schooling but not the test scores (cols. 7 and 8), we find point estimates for the test scores similar to those in columns 5 and 6 ; the estimated increase in the return to schooling is larger still and remains statistically significant. Hausman tests generally do not provide strong evidence against the joint hypothesis that both test scores and schooling are uncorrelated with the wage error term. However, the evidence aganst exogeneity is stronger when schooling is considered alone, with $p$-values of .096 (using both test scores) and .136 (using only the nonacademic test score).

${ }^{17}$ Rather than instrumenting for the education/trend interaction, we used the first-stage predicted value for education and interacted it with the trend variable in forming instruments since there is no reason to expect the trend variable to be correlated with the error term. This is the method of "internal instruments" (Bowden and Turkıngton 1984). Using standard IV technıques (1.e., forming the interactions and then instrumenting) yielded qualitatively similar coefficient estimates, but standard errors that were often three or four times as large as those in table 3; this latter finding parallels results in Bowden and Turkıngton 
We were concerned that our results may be partially driven by the failure to adequately control for interactive effects among the determinants of the wage. For instance, there may be an interaction between education and ability in wage equations; in particular, education may have a larger impact on the wages of more able workers. This may be particularly important given that, in our sample, individuals observed in the later years have both higher test scores and more schooling.

The first column of table 4 presents estimates for the specification in the second column of table 3 with an interaction between schooling and nonacademic ability as a regressor. ${ }^{18}$ The estimated coefficient of the education/nonacademic test interaction is positive and statistically significant and the education/trend coefficient estimate is reduced considerably. This result suggests that our finding of an increase in the return to schooling may be partly due to a combination of an ability/education interactive effect and the fact that average levels of ability are increasing over time in our sample. However, the estimates in columns 2 and 3 suggest that this interactive effect is much less important if we allow the education/nonacademic test coefficient to vary over time and also add interactions of the nonacademic test score with age, experience and a trend. ${ }^{19}$ For example, in column 3, the education coefficient estimate still displays an upward (although statistically insignificant) trend, though there is also some (slight) evidence that the education/nonacademic test coefficient is increasing over time.

It is not surprising that there is little evidence of an interactive effect of education and nonacademic ability since there is no clear reason why nonacademic ability would be expected to increase the beneficial effects of education. In columns 4-6 of table 4 , we repeat the estimations of columns $1-3$ using the academic test score in place of the nonacademic. Including an interaction between the academic test and education provides a significant coefficient estimate for the interaction and leaves the estimated increase in the schooling coefficient at essentially zero. This interactive effect of academic ability and schooling appears to be present primarily in the

\footnotetext{
${ }^{18}$ We estımated these specificatıons by OLS using the test scores as ability measures. Strictly speaking, this method of estımation is supported by the insignificant Hausman test statistics of table 3. Using different data, Blackburn and Neumark (1992) found that instrumenting was necessary when using an IQ test score, the difference in findings may be due to the ASVAB test scores being less error-prone than the IQ test scores in the other data. Below, however, we report results treatıng the test scores and schooling as correlated with the wage equation error

${ }^{19}$ To ease the interpretation of the coefficients, we have defined the levels of education, experience, and age used in the interaction variables as deviations from 12,2 , and 21 , respectively (near the sample means) Thus, e.g, in col. 3 the implied partial derivative of $\log$ wages with respect to the nonacademic test score, for an individual with 12 years of schooling, 2 years of experience, and aged 21, 1s simply the coefficient on the test score $(.052)$.
} 
Table 4

OLS Log Wage Equation Estimates, Alternative Trend and Interactive Specifications

\begin{tabular}{|c|c|c|c|c|c|c|c|c|}
\hline & (1) & (2) & (3) & (4) & (5) & (6) & (7) & (8) \\
\hline $\begin{array}{l}\text { Years of } \\
\text { education }\end{array}$ & $\begin{array}{c}026 \\
(009)\end{array}$ & $\begin{array}{c}025 \\
(.009)\end{array}$ & $\begin{array}{c}019 \\
(009)\end{array}$ & $\begin{array}{c}031 \\
(009)\end{array}$ & $\begin{array}{l}.029 \\
(009)\end{array}$ & $\begin{array}{c}025 \\
(009)\end{array}$ & $\begin{array}{l}.025 \\
(009)\end{array}$ & $\begin{array}{c}.023 \\
(009)\end{array}$ \\
\hline $\begin{array}{l}\text { Years of } \\
\text { education } \\
\times \text { trend }\end{array}$ & $\begin{array}{c}0015 \\
(0018)\end{array}$ & $\begin{array}{c}0015 \\
(.0018)\end{array}$ & $\begin{array}{c}0022 \\
(0019)\end{array}$ & $\begin{array}{c}0001 \\
(0019)\end{array}$ & $\begin{array}{c}-.0003 \\
(.0020)\end{array}$ & $\begin{array}{c}-0001 \\
(0021)\end{array}$ & $\begin{array}{l}-0003 \\
(0021)\end{array}$ & $\begin{array}{c}0004 \\
(0020)\end{array}$ \\
\hline $\begin{array}{l}\text { Nonacademic } \\
\text { test }\end{array}$ & $\begin{array}{c}.038 \\
(.006)\end{array}$ & $\begin{array}{c}036 \\
(006)\end{array}$ & $\begin{array}{c}052 \\
(009)\end{array}$ & & & & $\begin{array}{c}067 \\
(016)\end{array}$ & $\begin{array}{c}061 \\
(012)\end{array}$ \\
\hline $\begin{array}{l}\text { Nonacademic } \\
\text { test } \times \text { years } \\
\text { of education }\end{array}$ & $\begin{array}{l}009 \\
(002)\end{array}$ & $\begin{array}{c}006 \\
(003)\end{array}$ & $\begin{array}{l}.002 \\
(004)\end{array}$ & . & & . & $\begin{array}{c}005 \\
(007)\end{array}$ & - \\
\hline $\begin{array}{l}\text { Nonacademic } \\
\text { test } \times \text { years } \\
\text { of education } \\
\times \text { trend }\end{array}$ & . & $\begin{array}{c}.0008 \\
(0008)\end{array}$ & $\begin{array}{c}0010 \\
(0008)\end{array}$ & & . . & & $\begin{array}{r}-.0005 \\
(.0015)\end{array}$ & \\
\hline $\begin{array}{l}\text { Nonacademic } \\
\text { test } \times \text { trend }\end{array}$ & & & $\begin{array}{c}-.00+1 \\
(0028)\end{array}$ & & & & $\begin{array}{r}-0057 \\
(0050)\end{array}$ & $\begin{array}{r}-.0037 \\
(.0027)\end{array}$ \\
\hline $\begin{array}{l}\text { Nonacademic } \\
\text { test } \\
\times \text { experience }\end{array}$ & & & $\begin{array}{c}-005 \\
(004)\end{array}$ & & & - & $\begin{array}{c}-002 \\
(006)\end{array}$ & \\
\hline $\begin{array}{c}\text { Nonacademic } \\
\text { test } \times \text { age }\end{array}$ & $\cdots$ & . & $\begin{array}{c}010 \\
(003)\end{array}$ & & . & & $\begin{array}{c}006 \\
(.005)\end{array}$ & $\begin{array}{c}006 \\
(003)\end{array}$ \\
\hline Academic test & & & . & $\begin{array}{c}048 \\
(011)\end{array}$ & $\begin{array}{c}043 \\
(012)\end{array}$ & $\begin{array}{l}.058 \\
(.020)\end{array}$ & $\begin{array}{c}-043 \\
(.032)\end{array}$ & $\begin{array}{c}-021 \\
(.017)\end{array}$ \\
\hline $\begin{array}{l}\text { Academic test } \\
\times \text { years of } \\
\text { education }\end{array}$ & & & . & $\begin{array}{c}015 \\
(004)\end{array}$ & $\begin{array}{c}005 \\
(.007)\end{array}$ & $\begin{array}{l}-003 \\
(007)\end{array}$ & $\begin{array}{c}-004 \\
(.014)\end{array}$ & \\
\hline $\begin{array}{c}\text { Academic test } \\
\times \text { years of } \\
\text { education }\end{array}$ & & & & & & & & \\
\hline$\times$ trend & & & & - & $\begin{array}{c}0029 \\
(0014)\end{array}$ & $\begin{array}{c}0032 \\
(0015)\end{array}$ & $\begin{array}{c}0034 \\
(0028)\end{array}$ & $\begin{array}{c}0029 \\
(.0010)\end{array}$ \\
\hline $\begin{array}{l}\text { Academic test } \\
\times \text { trend }\end{array}$ & & & & & . & $\begin{array}{r}-0022 \\
(0054)\end{array}$ & $\begin{array}{c}0068 \\
(0094)\end{array}$ & \\
\hline $\begin{array}{l}\text { Academic test } \\
\times \text { experience }\end{array}$ & & & & & & $\begin{array}{c}-.012 \\
(.007)\end{array}$ & $\begin{array}{l}-007 \\
(011)\end{array}$ & \\
\hline $\begin{array}{l}\text { Academic test } \\
\times \text { age }\end{array}$ & & & . & & & $\begin{array}{c}019 \\
(005)\end{array}$ & $\begin{array}{c}009 \\
(009)\end{array}$ & $\begin{array}{c}009 \\
(007)\end{array}$ \\
\hline $\bar{R}^{2}$ & 409 & 409 & 411 & 402 & 403 & 405 & 413 & 414 \\
\hline
\end{tabular}

NOTE - Specifications also mnclude experience, age, and union status (each interacted with a time trend defined as zero in 1979), dummy variables for urban residence and married, spouse present, and an intercept and single-year dummy variables Standard errors are reported in parentheses OLS = ordinary least squares 
later years of our sample, as the estimate of the test-score/education/ trend coefficient is positive and statistically significant in columns 5 and $6 .^{20}$ If we include all interactions for both the academic and nonacademic test scores in the same equation (col. 7), the academic test/education/ trend coefficient estimate is still large but becomes statistically insignificant because of a much higher standard error. In column 8 , we exclude all variables with clearly insignificant coefficient estimates, leaving the academic test/education/trend coefficient estimate virtually unchanged but with a much smaller standard error. While any hypothesis testing associated with column 8 does suffer from pretest bias, the $t$-statistic of 2.9 is rather large. In addition, in both columns 7 and 8 , an estimated increase in the coefficient on education is no longer present.

Finally, the estimates reported in table 4 also contain some information on changes in the "price" of ability. As we noted earlier, increases in the price of abilıty, as well as a strengthened partıal correlation between ability and schooling, could have generated increases in returns to schooling over the 1980s. The point estimates in column 8 of table 4 suggest that, if anything, the coefficient for the nonacademic test has been declining. The positive coefficient for the academic test/education/trend interaction is consistent with an increase in the return to ability for the more highly educated. However, there is no evidence of an across-the-board increase in the price of academic ability; the coefficient estimates of the academic test/trend interaction in columns 6 and 7 are statistically insignificant.

Estımates of the coefficients involving test-score/trend interactions may be biased toward zero. Because the NLSY respondents took the ASVAB tests in 1979 and 1980, it is possible that the test scores are more accurate indicators of ability for observations close to these years and noisier indicators for observations later in the sample period. This increase in measurement error over the sample period could bias the results against finding an increase in the "price" of ability. To shed some light on this problem, for each of the two test scores we estimated the wage equation specification from table 2, column 1, adding the test score and the test-score/trend interaction. We estimated these specifications first using OLS, and then instrumenting for the test-score variables. If the test scores for the later observations are more error-ridden, then the IV estimation should remove the bras in the estimates of the test-score/trend coefficients and result in higher point estimates than the OLS estimation (when the latter are positive). However, for both the nonacademic and academic test scores, the

\footnotetext{
${ }^{20}$ Krueger (1991) finds that the increase in the return to schoolıng between 1984 and 1989 was larger for individuals reporting use of a computer at work. Since it seems plausible that these individuals have relatıvely high academic ability, this result is consistent with our finding of a positive coefficient for the test-score/ education trend.
} 
IV estimate of the coefficient of the test-score/trend interaction is lower than the OLS estimate. ${ }^{21}$ Thus, we do not believe that this source of measurement-error bias is a serious problem.

To summarize the findings from tables 3 and 4 , the increase in the return to education over the 1980 s persists when account is taken of the potential relationships between ability, schooling and wages. However, our investigation leads to a refinement of the finding: the increase in the return to education occurred for workers with relatively high academic ability. In fact, because the test scores are constructed to have means near zero, the estimates imply that most workers with below average academic ability experienced a decline in the return to schooling. ${ }^{22}$ Overall, then, existing estimates of the increase in the return to schooling, from data sets without ability measures, overstate the relative wage gains that education would have imparted to a randomly chosen (or marginal) worker.

\section{Robustness Checks}

Several checks of the robustness of our findings are reported in table 5. In each case, the first two columns report the OLS estimate of the education coefficient and its trend in specifications without ability controls. The next two columns report these coefficients' estimates from specifications that include the test-score interactions included in column 8 of table 4. We also report the academic test/education/trend coefficient estimate, and the estimate for the coefficient on the nonacademic test score.

First, we consider the effects of changes in the sample used in estimating the wage equations. We tried two alternative restrictions in selecting the sample. First, we excluded any individual with labor market experience greater than 3 years, to avo1d using individuals who may be firmly ensconced in the labor force and therefore not competing for a new job and to reduce the potential confounding influence of learning or signaling. Second, we excluded observations whose first postschooling jobs were in 1982 or 1983, to enhance the comparison between the low-schooling-return and high-schooling-return periods and to eliminate severe recession years.

${ }^{21}$ For the nonacademic test, the OLS estımate (standard error) of the test-score) trend interaction was .0033 (0023), and the IV estimate was 0024 (.0077); for the academic test the corresponding estimates were $.0097(.0046)$, and $-.0157(.0175)$. Instrumental variable estimates of the specification in col. 8 of table 4 (instrumenting for the test-score variables but not schooling) also suggest that instrumenting for the test scores reduces (if anything) the estimated change in the return to ability (for a worker with the average level of education)

${ }^{22}$ For example, consider a worker with an academic test score 1 standard deviation (.857) below the mean (.012), using the estimates in col. 8. The annual change in the return to schooling for this worker is $.0004+.0029 \cdot(-845)=-.0021$ Since, on average, more schooling is associated with higher test scores, this is not inconsistent with increased returns to schooling in wage regressions omitting ability measures 
Table 5

Schooling and Schooling $\times$ Ability Coefficients and Trend Interactions for Alternative Samples and Specifications

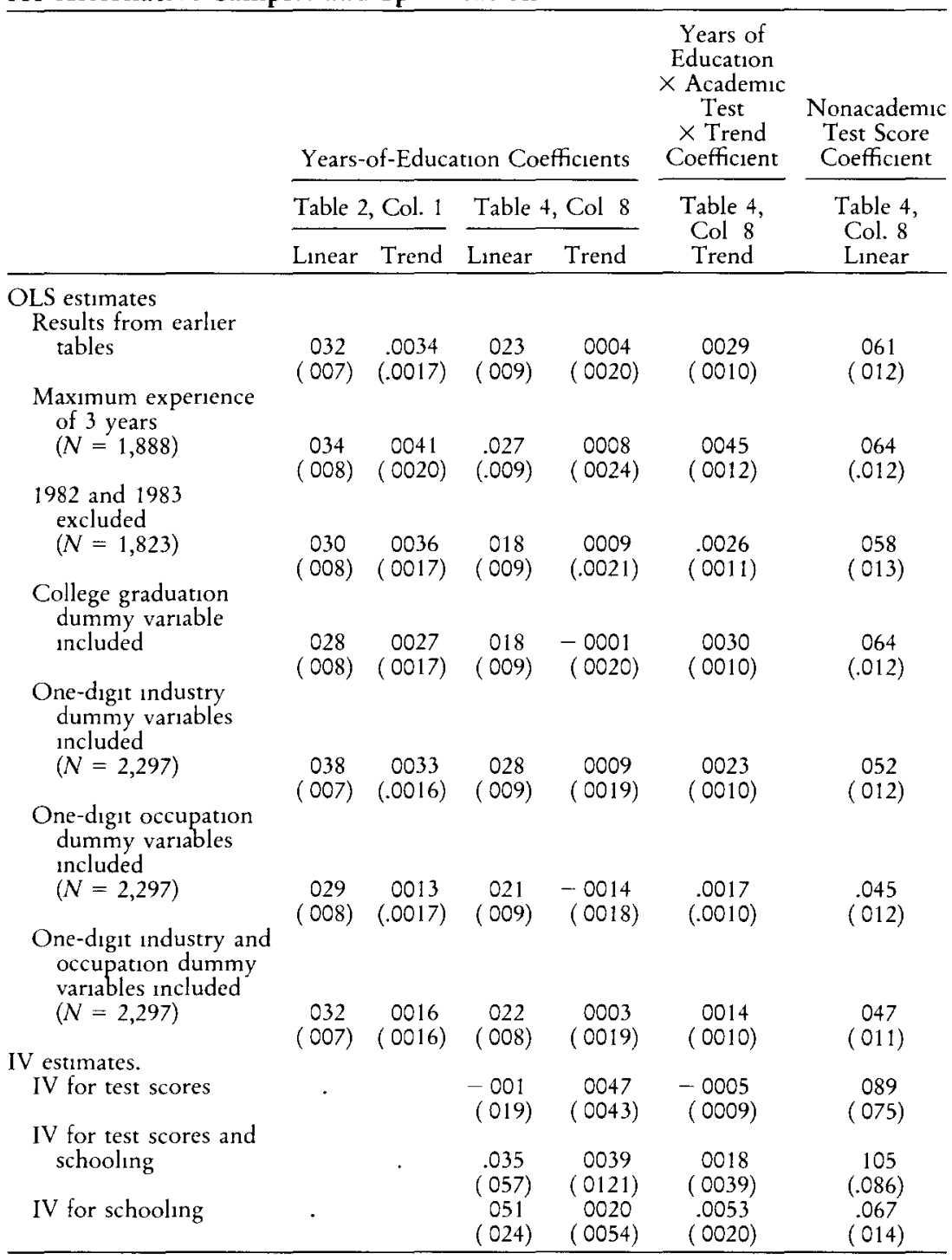

NOTE - See footnotes in corresponding tables I-+

Both redefinitions of the sample lead to similar conclusions as with the full sample, with the sample with the maximum-experience restriction providing a larger estimated increase in the academic test/education interaction effect than was provided by the full sample. 
Next, we consider alternative wage equation specifications. The fourth row of table 5 presents results from estimations that include a college graduation dummy; again, conclusions are essentially unchanged. We also estimated wage equations that include 12 industry and 11 occupation dummies as regressors; these results are reported in the next three rows of table 5. These estimates suggest that occupational shifts (but not industry shifts) can explain a considerable portion of the schooling return increase if we omit ability from the specifications. ${ }^{23}$ Occupation (and to a lesser extent industry) shifts also appear to account for at least part of the increase in the interactive effect of academic ability and education, suggestıng that at least part of the increased importance of education to wages for highacademic-ability males is due to demand shifts toward occupations (and industries) that tend to employ high-education/high-ability individuals.

Finally, we report estimates of the specification reported in column 8 of table 4, treating the test scores and/or schooling as potentially correlated with the wage equation error. In the two estimations in which we instrument for the test score variables, the previous finding regarding the increase in the return to schooling - that it occurred only for high-ability workersis not supported, but the point estimate of the education/trend coefficient increases (and is marginally significant when we instrument for test scores only). However, none of the reported coefficients is statistically significant; the imprecision of these estimates is not surprising, given the number of variables constructed from fitted values based on the same set of exogenous variables. Finally, the last row of the table reports results instrumenting for schooling only. Based on the evidence from the Hausman tests in table 3 , schooling is the variable for which the evidence against exogeneity is strongest. These estimates replicate the OLS estimates in table 4, yielding a statistically insignificant (and negative) estımate for the education coefficient trend and a statistically significant positive coefficient for the trend in the academic test score/education interaction.

\section{Summary}

Much attention has been paid to explaining recent increases in the return to schooling among males in the United States. Estımates of these increases are generally obtained from wage regressions that are potentially biased by the presence of "unobserved" ability in the wage-equation error. Both signaling and human-capital models of educational attainment suggest that changes in the relationship between ability and schooling could underlie increases in the observed return to schooling. We offer evidence on the

${ }^{23}$ This finding differs from that of Blackburn, Bloom, and Freeman (1990), who found that changing industrial composition of employment explains up to $25 \%$ of the increase in education-related earnings differentrals but that occupational changes played no role in the schooling-return increase 
plausibility of these explanations, with a particular focus on using test scores as a proxy for ability in wage regressions. Our results provide little or no support in favor of the hypothesis that the increases in the return to schooling reflect an increased upward bias in the schooling coefficient estımate due to a change in the ability-schooling relationship. But our results do provide an interesting refinement of the stylized fact that education returns have been increasing in the 1980 s-the increase in the return to education has occurred only for workers with relatively high levels of "academic" ability. This implies that existing estimates of the increase in the return to schooling overstate increases in the true incentive for the marginal individual to acquire schooling.

What can explain an increase in the return to education for high-ability workers only? Supply-side explanations are plausible. For example, if it were the case that education and ability were becoming less correlated over time, then there would be relatively fewer of those workers with both high levels of education and ability; also, if the average level of ability were to fall, this could create a growing scarcity of high-education, high-ability workers. But at present it is difficult to assess the existence or importance of such supply-side changes. ${ }^{24}$ While occupation shifts appear to be of some importance, what is causing these shifts is still an open question. Skill-biased technical change is one possibility, though the evidence in favor of this argument is still limited. ${ }^{25}$

\section{Appendix}

Table A1

Individual-Year Schooling Coefficient Estimates

\begin{tabular}{ll}
\hline Year & Coefficient \\
\hline 1979 & $021(011)$ \\
1980 & $.048(011)$ \\
1981 & $.039(.011)$ \\
1982 & $.051(.012)$ \\
1983 & $.041(012)$ \\
1984 & $.039(013)$ \\
1985 & $.062(015)$ \\
1986 & $.050(.015)$ \\
1987 & $.050(021)$ \\
\hline
\end{tabular}

NOTE - Standard errors are reported in parentheses

${ }^{24}$ In fact, Bishop (1991) refers to results that suggest that average test scores of young individuals started to increase again after 1980.

${ }^{25}$ Krueger (1991) argues that his results are consistent with the technical-change hypothesis. Davis and Haltıwanger (1991) offer evidence on changes in wage dispersion across manufacturing plants that, they argue, supports the skill-biased technical-change hypothesis. Mincer (1991) offers time-series evidence in favor of the skill-bias hypothesis 
Table A2

Schooling Coefficient Estimates from

Test-Score Regressions

\begin{tabular}{lll}
\hline Year & Academic & Nonacademıc \\
\hline 1979 & $243(022)$ & $513(046)$ \\
1980 & $275(021)$ & $503(045)$ \\
1981 & $.291(025)$ & $476(054)$ \\
1982 & $.278(020)$ & $401(042)$ \\
1983 & $225(023)$ & $342(043)$ \\
1984 & $258(.022)$ & $347(044)$ \\
1985 & $246(.024)$ & $356(045)$ \\
1986 & $191(020)$ & $249(.038)$ \\
1987 & $132(027)$ & $183(050)$ \\
\hline
\end{tabular}

NOTE - Standard crrors are reported in parentheses

Table A3

Coefficients of Instrumental Variables in First-Stage Regressions

\begin{tabular}{|c|c|c|c|}
\hline & $\begin{array}{c}\text { Nonacademic Test* } \\
\text { (1) }\end{array}$ & $\underset{(2)}{\text { Academic Test* }}$ & $\begin{array}{l}\text { Schooling } \\
\text { (3) }\end{array}$ \\
\hline Magazınes in home (age 14) & $\begin{array}{c}.231 \\
(.060)\end{array}$ & $\begin{array}{c}149 \\
(030)\end{array}$ & $\begin{array}{c}484 \\
(073)\end{array}$ \\
\hline Newspapers in home (age 14) & $\begin{array}{l}311 \\
(077)\end{array}$ & $\begin{array}{l}108 \\
(038)\end{array}$ & $\begin{array}{c}152 \\
(095)\end{array}$ \\
\hline Library card in home (age 14) & $\begin{array}{l}067 \\
(061)\end{array}$ & $\begin{array}{l}076 \\
(030)\end{array}$ & $\begin{array}{l}145 \\
(075)\end{array}$ \\
\hline Father's education (1979) & $\begin{array}{l}029 \\
(010)\end{array}$ & $\begin{array}{c}015 \\
(005)\end{array}$ & $\begin{array}{l}080 \\
(012)\end{array}$ \\
\hline Mother's education (1979) & $\begin{array}{l}072 \\
(013)\end{array}$ & $\begin{array}{l}036 \\
(006)\end{array}$ & $\begin{array}{l}.094 \\
(016)\end{array}$ \\
\hline Number of siblings (1979) & $\begin{array}{r}-047 \\
(019)\end{array}$ & $\begin{array}{l}-037 \\
(010)\end{array}$ & $\begin{array}{l}-151 \\
(022)\end{array}$ \\
\hline Number of older siblings (1979) & $\begin{array}{l}015 \\
(024)\end{array}$ & $\begin{array}{l}015 \\
(012)\end{array}$ & $\begin{array}{c}086 \\
(029)\end{array}$ \\
\hline $\begin{array}{l}\text { Highest grade of oldest sibling } \\
\text { (1979) }\end{array}$ & $\begin{array}{l}029 \\
(014)\end{array}$ & $\begin{array}{c}012 \\
(007)\end{array}$ & $\begin{array}{c}105 \\
(017)\end{array}$ \\
\hline $\begin{array}{l}\text { Foreign language spoken in home } \\
\text { (age 14) }\end{array}$ & $\begin{array}{l}.011 \\
(082)\end{array}$ & $\begin{array}{l}-052 \\
(041)\end{array}$ & $\begin{array}{l}177 \\
(100)\end{array}$ \\
\hline Father and mother in home (age 14) & $\begin{array}{c}-062 \\
(082)\end{array}$ & $\begin{array}{l}-029 \\
(040)\end{array}$ & $\begin{array}{c}387 \\
(.100)\end{array}$ \\
\hline No adult male in home (age 14) & $\begin{array}{l}-024 \\
(106)\end{array}$ & $\begin{array}{c}-021 \\
(.052)\end{array}$ & $\begin{array}{l}187 \\
(130)\end{array}$ \\
\hline $\bar{R}^{2}$ & 368 & 502 & 625 \\
\hline
\end{tabular}

NOTE - Coefficients are reported for first-stage regressions using linear schoolng Specifications also include intercepts, single-year dummy variables, all other variables included in specifications of wage equations in table 3, and dummy variables for each variable in the table set equal to one when data were missing on the instruments (in which case the variables were set equal to $7 \mathrm{ero}$ ) (We distinguish between the highest grade of oldest sibling missing in the usual sense and missmg because the respondent is the oldest sibling) Standard errors are reported in parentheses

* Specification includes schooling and its trend interaction 


\section{References}

Becker, Gary S. Human Capıtal. 2d ed. Chicago: Universıty of Chicago Press, 1975.

Bishop, John H. "Is the Test Score Decline Responsible for the Productivity Growth Decline?" American Economic Review 79 (March 1989): 17897.

_. "Achievement, Test Scores, and Relative Wages." In Workers and Therr Wages. Changing Patterns in the Unted States, edited by Marvin H. Kosters. Washington, D.C.: American Enterprise Institute Press, 1991.

Blackburn, McKinley L.; Bloom, David E.; and Freeman, Richard B. "The Declining Economic Position of Less-Skilled American Men." In $A F u-$ ture of Lousy Jobs? The Changing Structure of U.S. Wages, edited by Gary Burtless. Washington, D.C.: Brookings Institution, 1990.

- "An Era of Fallıng Earnings and Rising Inequality?" Brookings Review 9 (Winter 1990/91): 38-43.

Blackburn, McKınley L., and Neumark, David. "Omitted-Ability Bias and the Increase in the Return to Schooling." Working Paper no. 3693. Cambridge, Mass.: National Bureau of Economic Research, May 1991. _. "Unobserved Ability, Efficiency Wages, and Interindustry Wage Differentials." Quarterly Journal of Economics 107 (November 1992): 1421-36.

Bowden, Roger J., and Turkington, Darrell A. Instrumental Variables. Cambridge: Cambridge University Press, 1984.

Davis, Steve J., and Haltiwanger, John. "Wage Dispersion Between and Within U.S. Manufacturing Plants, 1963-1986." In Brookings Papers on Economic Activity: Microeconomics, 1991. Washington, D.C.: Brookings Institution, 1991.

Farber, Henry, and Gibbons, Robert. "Learning and Wage Determination." Unpublished manuscript. Cambridge, Mass.: Massachusetts Institute of Technology, August 1990.

Griliches, Zv1. "Estimatıng the Returns of Schooling: Some Econometric Problems." Econometrica 45 (January 1977): 1-22.

- "Sibling Models and Data in Economics: Begınnings of a Survey." Journal of Polutzcal Economy 87, no. 5, pt. 2 (October 1979): S37-S64.

Griliches, Zvi, and Mason, William M. "Education, Income and Ability." Journal of Political Economy 80, no. 3, pt. 2 (June 1972): S74-S103.

Harris, Milton, and Holmstrom, Bengt. "A Theory of Wage Dynamics." Review of Economic Studies 44 (July 1982): 315-33.

Hausman, Jerry A. "Specification Tests in Econometrics." Econometrica 46 (November 1978): 1251-71.

Katz, Lawrence F., and Murphy, Kevin M. "Changes in Relative Wages, 1963-1987: Supply and Demand Factors." Quarterly Journal of Economics 107 (February 1992): 35-78.

Katz, Lawrence F., and Revenga, Ana L. "Changes in the Structure of Wages: The United States vs. Japan." Journal of the Japanese and International Economies 3 (December 1989): 522-53.

Kmenta, Jan. Elements of Econometrics. 2d ed. New York: Macmillan, 1986 
Kosters, Marvin H. "Wages and Demographics." In Workers and Their Wages: Changing Patterns in the United States, edited by Marvin H. Kosters. Washington, D.C.: American Enterprise Institute Press, 1991.

Krueger, Alan B. "How Computers Have Changed the Wage Structure: Evidence from Microdata, 1984-1989." Unpublished manuscript. Princeton, N.J.: Princeton University, June 1991.

Mincer, Jacob. "Human Capital, Technology, and the Wage Structure: What Do Time Series Show?" Working Paper no. 3581. Cambridge, Mass.: National Bureau of Economic Research, January 1991.

Spence, Michael A. "Job Market Signaling." Quarterly Journal of Economics 87 (August 1973): 355-75.

Taubman, Paul, and Wales, Terence. "Mental Ability and Higher Educational Attainment in the 20th Century." Occasional Paper no. 118. New York: National Bureau of Economic Research, 1972. 
Copyright of Journal of Labor Economics is the property of University of Chicago Press and its content may not be copied or emailed to multiple sites or posted to a listserv without the copyright holder's express written permission. However, users may print, download, or email articles for individual use. 